\title{
International Social Entrepreneurship and Social Value Creation in Cause- Related Marketing through Personal Relationships and Accountability
}

\begin{abstract}
Drawing on the resource based view (RBV) and literature on relational embeddedness and network ties, we examine how personal relationships of international social entrepreneurs and accountability of social enterprises influence social value creation in cause-related marketing (CRM) of three UK-based international charities. The study also explores how personal relationships of international social entrepreneurs affect accountability of social entrepreneurship for social value creation of non-profit organizations in the UK context. The findings revealed through the case study method highlight the importance of personal relationships between charity and commercial organizations across borders closely allying corporate social responsibility. In international social entrepreneurship, social value creation is facilitated by accountability of social goals while trust-based personal relationships assist access to commercial opportunities.
\end{abstract}

Keywords: International social entrepreneurship; Value creation; Relational embeddedness; Personal ties; Accountability. 


\section{International Social Entrepreneurship and Social Value Creation in Cause- Related Marketing through Personal Relationships and Accountability}

\section{Introduction}

In response to growing competition and declining availability of third-sector donor funds, non-profit organizations and charities are increasingly seen to engage in cause related marketing activities (CRM) through international social entrepreneurship with commercial counterparts (Bornstein, 2007; Schiller \& Almog-Bar, 2013; Vanhamme et al., 2012). The international social entrepreneurship is an important means where organisational identity enhances and allows both organizations and their members to align their commercial objectives with their moral and social identities (Berger, Cunningham, \& Drumwright, 2006). International social entrepreneurs are ventures which develop innovative marketing solutions to social problems through entrepreneurial activity (Desa, 2012). They are particularly prevalent in mature economies including the United Kingdom through schemes such as regeneration of deprived towns and/or communities to create employment opportunities and spur economic growth. However, implementation of social entrepreneurship for CRM in an international context is challenged by varying legal requirements, supportive institutions and importance assigned to social issues (Desa, 2012). Therefore, in international social entrepreneurship implemented across borders, understanding the role of accountability in social value creation during CRM becomes highly important.

One critical aspect of entrepreneurship is the ability to mobilize external resources connected to the firm through personal relationships (Hite, 2005; Eng et al. 2012). In this regard, international social entrepreneurs with limited organizational 
resources would seek to exploit, access, develop and combine relationally embedded ties or relationships for advancing social and business goals (Uzzi 1997). While there are clear economic benefits from exploiting relational ties in networks, social entrepreneurs are in a unique position of achieving the two seemingly conflicting social and commercial interests. Since interpersonal relationships usually serve as a starting point for entering into formalised relationships and have been demonstrated as a key factor in the internationalisation process (Simon \& Wheeler, 2015), the present study focuses on the role of personal relationships and accountability in international social entrepreneurship.

The limited number of studies on social entrepreneurship have highlighted the importance of relational ties (e.g. Nandan et al., 2019; Zafeiropoulou \& Koufopoulos, 2013) and accountability (Caldwell et al., 2017; Molecke \& Pinkse, 2017) to attract financial and other types of support as well as creating social impact. However, till now, the social impact implications of relational ties have been studied at the organizational level. The literature on international social entrepreneurship has not considered how international social entrepreneurs' personal relationships at the individual level may impact accountability of social entrepreneurship for CRM and social value creation. This is despite the fact that entrepreneurial-minded workers are encouraged to display more accountability values (Bonnstetter, 2012), and individual attributes and behaviours of entrepreneurs have been commonly identified as most critical determinant for business creation and growth (Bianchi et al., 2011). In this context, first, there is a need to understand how personal relationships of individual international social entrepreneurs with external stakeholders would influence accountability of social entrepreneurship for CRM and social value creation at the organizational level. As such, the initial objective of this study is to understand how personal relationships of 
international social entrepreneurs affect accountability of social entrepreneurship for social value creation of non-profit organizations in CRM.

Second, prior studies on entrepreneurial networks and network ties have examined the role of relational embeddedness and structural characteristics for the discovery of opportunities and mobilization of resources (e.g. Shane \& Venkataraman, 2000; Hite, 2005; Burt, 1992; Wang et al., 2019). This study builds on this knowledge by examining the processes in which international social entrepreneurs use their personal relationships to access and utilise external resources for social value creation in CRM. In addition, the study the study extends the limited insights of previous studies on international social entrepreneurship among organisations with reference to CRM where social value attributes are evaluated by embedded relational ties. Therefore, the second objective of this study is to explore how personal relationships of international social entrepreneurs enable exploitation of external resources for social value creation in CRM.

Third, while the literature on non-profit organizations recognises the significance of social networks for collaboration, partnership and innovation (e.g., Perrini \& Vurro, 2006; Mair \& Schoen, 2005), little is known about how accountability of social entrepreneurship for CRM in relationally embedded ties impacts on social value creation especially in international partnerships. This is important to address because it has been implied that social actors' tendency to be accountable may be contingent on the degree of their relational ties with others (Leavitt et al., 2012). In this sense, the third objective of this study is to understand how accountability in international social entrepreneurship in relationally embedded ties may influence social value creation in CRM. Drawing on the resource based view (RBV) and literature on relational embeddedness and network ties, the study examines the role of personal 
relationships and accountability in social value creation of three UK-based international charities in their CRM activities.

\section{Literature Review}

\subsection{International Social Entrepreneurship}

The context of social entrepreneurship has been widely discussed with reference to the social component of entrepreneurship (Weerawardena \& Mort, 2006) and the differences from commercial entrepreneurship (Spear, 2006; Austin, Stevenson, \& Wei-Skillern, 2006). Where the social component is weighted for its content and importance, it is measured against profit-making goals, i.e. corresponding to incorporation and capitalization (Peredo \& McLean, 2006). A dichotomy of profit motive in business entrepreneurship versus pure altruism in social entrepreneurship is a key construct (Mair and Marti, 2006).

Social entrepreneurs are positioned uniquely to exploit social aspects of ethical responsibility while being able to fulfil the commercial interests of their for-profit alliances (Zahra et al., 2009; Schaltegger \&Wagner, 2011). Social enterprise has been defined by the UK Government as 'a business with primarily social objectives whose surpluses are principally reinvested for that purpose in the business or in the community, rather than being driven by the need to maximize profit for shareholders' (Chell , Nicolopoulou \& Karataş-Özkan, 2010). Social entrepreneurs' manifest dual characteristics of financial sustainability and value-driven social purpose. Therefore, a singular construct of identifying inherent values of social entrepreneur is rather narrow. Dees (1998) observes that social entrepreneurs prioritise social value over economic value, even though they actively seek commercial incomes to diversify their sources of 
revenues. However, it is often challenging to measure social value and interpret how it is created (Choi and Majumdar 2014).

Doherty, Haugh, and Lyon (2014) also reviewed research on social enterprises, considering them as hybrid organizations that pursue the dual mission of financial sustainability and social purpose. The study conducted by Doherty et al. (2014) focused on the hybridity of social entrepreneurial firms, to assess its impact on the combination of management of mission, acquisition of financial resources and mobilization of human resources by the social entrepreneur. The up-scaling of financial resources of social entrepreneurial firms stems from the economic sterilization rather than profitseeking proclivity. Whereas, the human resource mobilization emanates from the competency based social attributes such as socio-cognitive and interpersonal skills.

Social entrepreneurs operate differently within the context demographic spread and differ as to how they generate, share and capture the value (Lepoutre, Justo, Terjesen, \& Bosma, 2013). While value generation is enabled by human capabilities and inherent attributes, value sharing and capturing occur through the social mobility across countries and culture. According to Zahra and George (2002), international social entrepreneurship is the "process of creatively discovering and exploiting opportunities that lie outside a firm's domestic markets" (p. 261). Based on their view, Tukamushaba et al. (2011) suggest that international social entrepreneur ideally needs to have presence in its "domestic market" but might launch his enterprise in another country if there is no entrepreneurial avenues in its domestic market, which is commonly seen in social entrepreneurship. In an international diaspora, the changing business and entrepreneurial values can be enhanced through the practice of truthfulness, simplicity, expanded participation and personal responsibility (Czinkota, 2017). Social entrepreneurship in Portugal was studied in third sector organizations by 
Parente et al. (2012) using 20 semi-structured interviews to explore differences between the North American concept of social entrepreneur, the traditional European school and Latin American semi-peripheral school of solidarity economics. Their results highlighted that the North American school links social entrepreneurship with personal intrinsic qualities of the entrepreneur and use of business solutions for sustainability and economic efficiency of the enterprise. On the other hand, the European perspective focused on two dimensions - i.e. political and economic - to promote civic, democratic, and participative philosophy that follow principles of redistribution and reciprocity in monetary and non-monetary terms for managing solidarity in relationships. The European context traditionally attributes social entrepreneurship to shared and complementary economic and civic values (Hlady-Rispal and Servantie, 2016). Despite variation across countries and levels of authority in European union, the policy communities expound the quasi-concepts of social investment and social entrepreneurship in combination as the appropriate ways to govern financing and the delivery of social investments (Jensen, 2017).

The RBV offers a framework for understanding how resources and capabilities enhance a firm's competencies and enable it to serve its target market more effectively (Desa and Basu 2013). One critical aspect of international entrepreneurship is the ability to mobilize external resources connected to the firm through personal relationships (Hite, 2005; Eng et al., 2012) and develop entrepreneur-centered stewardship (Bacq \& Eddleston, 2018). In particular, RBV perspective suggests social enterprises as organizations whose scale of social impact is dependent on their ability to build, combine, and apply resources and capabilities. In this regard, social entrepreneurs, restricted with environmental constraints and with limited organizational resources, would seek to exploit, access, develop and combine relationships, i.e. relationally 
embedded ties for advancing social and business goals (Chell, Nicolopoulou, \& Karatas-Ozkan, 2010; Uzzi, 1997). Access to resources has further complications in international social entrepreneurship. This is because international social entrepreneurs need to balance between social and commercial needs while managing the peculiarities of diverse institutional contexts and social contradictions. The RBV is consistent with the importance of cooperation and support in achieving an enterprise's social goals (Bacq \& Eddleston, 2018). Five topic clusters are identified within the field of Social Entrepreneurship: 1) Definitions and conceptual approaches, 2) Impetus, 3) Personality, 4) Impact and performance, and 5) Future research agenda (Kraus et al., 2014). We are predominantly focusing our study based on impact and performance aspect of social entrepreneurship associated with personal relationships and accountability. While there are clear economic benefits from exploiting relational ties in networks, social entrepreneurs are in a unique position of achieving the two seemingly conflicting interests, i.e. to manage the tension between social welfare and commercial success (Zhu, Rooney, \& Phillips, 2016). In particular, this can be challenging for international social entrepreneurship as interpersonal relationships usually serve as a starting point for entering into formalised relationships.

\subsubsection{International Social Entrepreneurship in CRM}

CRM refers to a social initiative in which social enterprises gain donations for a particular cause as a result of every consumer purchase made (Adkins 1999; Varadarajan and Menon 1988; Vanhamme et al., 2012). Commercial firms engage in CRM activities with social enterprises to gain reputation and legitimacy, and as a result to attract more customers and greater talents, and to achieve improved financial performance (Vanhamme et al., 2012). 
Scholarly studies such as Martin and Osberg (2015) highlighted social entrepreneurs as agents of change who use CRM to bring transformation at the societal level by focusing on their ability to find solutions to unjust and unsustainable systems. Authors like Arslan et al. (2020) extended the concept of social entrepreneur to international social entrepreneurship context by studying the case of a microfirm that consisted of only two employees (football talent scouting firm) to understand how internationalisation influence CRM through legitimacy. The study looks at use of customer relationship theories and models with socio-political legitimacy for gaining trust to explain different types of legitimacies required by social entrepreneurs in an international context and how customer relationships become useful to build internationally dispersed social partnerships.

\subsection{Relational embeddedness}

Relational embeddedness describes interpersonal relationships developed by interactions during a specific period (Granovetter, 1992). Relational embeddedness, one facet of social capital, facilitates the obtaining process of scarce resources ( $\mathrm{Li}$, Wang, Huang, \& Bai, 2003). It can be measured based on the relational tie strength between at least two entities (Rowley, Behrens, \& Krackhardt 2000). Since the concern is the social relationship, relationally embedded ties have been examined through modes of governance such as trust and relational contracting, rather through formal mechanisms of market governance such as contracts (Granovetter, 1985; Uzzi, 1996, 1997; Mitchell et al., 2016). Therefore, relationally embedded ties, particularly personal relationships emerge and embed relatively faster than achieved embeddedness. Social entrepreneurs interact with a number of stakeholders ranging from employees, 
customers, community and volunteers to donors through relational ties (Ramus \& Vaccaro, 2017; Park \& Ghauri, 2015). Particularly, emerging entrepreneurial firms rely initially on close and relationally embedded ties, such as personal relationships (Hite \& Hesterly, 2001; Musteen, Francis, \& Datta, 2010; Eng et al., 2012). Personal relationships provide social resources (Bates, 1997) and give the individual entrepreneur self-confidence, support, and motivation (Manning, Birley, \& Norburn, 1989). Importantly, relational ties in foreign markets support entrepreneurs to explore potentially valuable opportunities in their new market entries (Domurath \& Patzelt, 2016). More specifically, personal relationships facilitate access to resources through trust and informal knowledge about potential partners (Eberhard \& Craig, 2013). Within personal relationships, it is possible to describe the benefits of exchange and interaction between partners as social capital (Chang \& Gotcher, 2007; Eberhard \& Craig, 2013). Social capital is seen as a collective and valuable resource for survival, which may have positive economic and social impact (Bourdieu, 1997; Nahapiet \& Ghoshal, 1998; Liu, Eng, \& Ko 2013). Social capital effectively serves as a resource for action and integrates entrepreneurial structure into relational ties. For social entrepreneurs, access to networks of international resources may increase social impact or bestow legitimacy through accountability, and diminish risks (Granovetter, 1985) and enhance business capabilities and information (Gnyawali \& Fogel, 1994).

\subsection{The role of personal relationships in creating competence-based trust}

Relational exchange research demonstrates that the history of interaction between partners is a significant determinant of embedded relationships (Liu, Ghauri, \& Sinkovics, 2010; Kiessling, Harvey, \& Moeller, 2012; Carney, Dieleman, \& Taussig, 
2016). Literature has conceptualised exchange as transactional and relational (Aswo \& Gerald, 2019). Relational exchange enhances the knowledge-sharing and is central to competence-based and benevolence-based trust. Repeated interactions between the same partners enable learning about each other's competencies leading toc ompetencybased trust (Bonner \& Walker, 2004). The formation of competency-based trust between the partner firms limits the transaction-based costs associated with their future interactions (Gulati, 1995). The transactional cost within enterprise structure can potentially decrease the knowledge-transfer. Therefore, it encourages cooperative engagements between the partner firms (Mair \& Martí, 2006). The competence-based trust acts as a mediator between strong relational ties and receipt of useful knowledge (Levin \& Cross, 2004). These imply that the effect of relational ties between partner firms on social value creation can be mediated through competence-based trust (Doern \& Fay, 2006). In the context of social relationship, utilization of useful knowledge can help organizations to create social value (Chang \& Gotcher, 2007; Hong \& Nguyen, 2009). Similar to the commercial enterprises, in order to attract funds and resources, social enterprises need to build trust among their contributors (Austin et al., 2006). For example, a decreasing level of trust suggests ethical failures of enterprises (Czinkota, 2017). The benevolence-based trust can improve the competence-based trust, where relational ties assumes a more refined dimension of sharing (Levin and Cross, 2004)

\subsection{International social entrepreneurship and accountability}

Accountability often involves a relationship between parties, groups, or individuals and is a mechanism for guiding the behavior of people involved. (Burga \& Rezania,2015). Accountability is ambiguous as a term, complex and context dependent (Williams \& Taylor, 2013). From the descriptive sense, it is possible to view accountability in a 
social context as a holistic framework in the not-for-profit sector, the public sector, or private sector (Williams \& Taylor, 2013). Typically, social entrepreneurs can be referred to as individual change makers and innovators, who pursue a social mission often found in non-profit sectors (Grenier, 2006). Social entrepreneurs have evolved from the paradigm of social co-operative to value-integrated social entrepreneurship. Social entrepreneurs are also concerned with the application of business expertise and market skills to the non-profit sector with the aim to improve efficiency and effectiveness, and to search for alternative funding strategies and management schemes to create social value that generates financial impact (Boschee, 1995; Thompson, Alvy, \& Lees, 2000; Thompson, 2002; Austin et al., 2006). As such, social entrepreneurs experience mounting challenges in mmanaging the balance between resource utilization and engagement with local stakeholders in order to build and maintain organizational legitimacy (Moizer \& Tracey, 2010). Given that social entrepreneurs not only seek social value but conscious of financial impact, the role of enterprise resource allocation within non-profit sectors has significant bearing on social welfare and typically countermands the benefit retrenchments. Nicholls (2006) categorizes this group as social enterprise or low-level entrepreneurship. Within social entrepreneurship, international social alliances account for cross sector collaborations or partnerships between non-profits and social entrepreneurs and business (see Sagawa \& Segal, 2000; Austin 2000, 2006). Thus, social entrepreneurship is mainly concerned with the strategic primacy of social mission following an entrepreneurial innovative approach to serve the mission (Dees, 1998) and linked to accountability in non-profit organizations (Ospina, Diaz, \& O’Sullivan, 2002).

Accountability is a key element in the 'social' part of the definition of social entrepreneurship (Kolk, 2016; Aguilera \& Crespi-Cladera, 2016). Social dimensions of 
entrepreneurship are shrouded by opacity with challenges to rationalise and marketise the accountability (Molecke \& Pinkse, 2017). While social entrepreneurship is a critical and synthetic concept of social mission, the onus to sustain a continued accountability for the social entrepreneurs is challenging. Particularly, to recognize and utilise the opportunities to translate into social values while maintaining accountability with less restriction.

The definition of social entrepreneurship adopted above corresponds to the role of financial measures in commercial enterprise to fulfil stakeholder interests (Luke, Barraket, \& Eversole, 2013; Bagnoli \& Megali, 2011). Financial measures in business enterprises are often driven to wealth-maximization of shareholders, as compared to value creation through coproduction. The dimension of accountability characterizes the relationships with key stakeholders, i.e. beneficiaries and investors, and the outcomes as well as impact metrices (Kearns, 1996). The stakeholder relationships serves as accountability toward (1) the constituencies served, entailing an in-depth assessment of needs and values of clients served, (2) the community in which the social entrepreneur operates, (3) actual social improvement for its beneficiaries, and (4) the outcomes created, entailing investors' (time, money and expertise) expectations of attractive returns for these (social impact) (Dees, 1998). In addition, accountability includes the integration of investor values and community needs, and the creation of market-like feedback mechanisms and progress assessment (Barman, 2015; Czinkota \& Ronkainen, 2005). This responsibility can be achieved through the principle of shared value, which involves creating economic value in a way that also creates value for society by addressing its needs and challenges. (Porter \& Kramer, 2019) Accountability can inculcate the investors' interest in community values by formalising a coherent socioeconomic index. Accountability of social entrepreneurs goes beyond financial health, 
internal controls and regulatory compliance to include the demonstration of the fulfilment of public expectations and organizational goals (Kearns, 1996). Such a broad scope of accountability environment makes it difficult to assess and/or develop outcome measurement (Benjamin, 2012) especially as social entrepreneurs often make claims on behalf of beneficiaries (Kissane \& Gingerich, 2004). Thus, it is important to reconcile accountability of social entrepreneurship with regard to social value creation (Kolk, 2016; Danis, 2003).

\subsection{Social value creation}

$<$ Take in Table 1 about here $>$

Social value creation emphasizes social value that is difficult to quantify in financial terms and is created by means of innovation through network ties at different levels of an organization that impact on different stakeholders (Zahra et al., 2009). It leverages the unique resources and expertise of the company to create economic value by creating social value (Porter \& Kramer, 2019). Stakeholders are more susceptible to scrutinize and make sense of measurable terms, rather than network ties that duly go beyond traditional performance measures. Table 1 provides a review of social impact assessment methods.

As stated earlier, social entrepreneurs are driven by certain social objectives and commercial interests. On the other hand, international social entrepreneurs face greater challenges than commercial entrepreneurs in creating social value beyond national borders as well as quantifying performance measures (e.g., market share, financial performance ratios) to include multiple causes, temporal dimensions and perceptive 
differences (Austin et al., 2006). While the commercial counterpart has accepted accounting principles for reporting financial returns, a comparable standard for social impact accounting has not yet been established (Clark et al., 2003). The diverging perspectives towards set accounting principles and social accounting with value ingrained principles are critical to accountability and sustainability. Some of the best practices have been documented in the literature (e.g., Nicholls, 2006; Benjamin, 2012) through a combination of social impact assessment methods, including economic financial performance, social effectiveness and institutional legitimacy (Bagnoli \& Megali, 2011). Some scholars suggest a combination of performance measures with social impact to include the environmental and social value created through economic activity (e.g., Elkington, 2004; Alter, 2007; Grieco, Michelini, \& Iasevoli, 2014). As shown in Table 1, non-profit beneficiaries and investors would occupy an equally important place at the top of the balance scorecard (Kaplan, 2001). Kaplan (2001) stresses that the strategy and performance measures in a non-profit or social venture need to be focused on outputs and outcomes an organization wants to achieve, rather than programmes and initiatives implemented. However, the impact methods have not been empirically examined with reference to relational embeddedness, considering the potential to create social value and/or generate social impact. The dyadic nature of output versus organizational outcome can potentially converge to relational embeddedness if social value alignment occurs between stakeholders.

\section{Research Methodology}

\subsection{Research Approach}

The case study method is a research strategy with strong philosophical underpinnings which provides a framework for exploratory research in real-life settings (Yin, 2009). 
The case study research strategy is deemed most appropriate to investigate social value creation in a real-life context where sources of value, processes and personality and value system of the initiative's founders are all inextricably interlinked (Mair \& Noboa, 2005)

The literature on social value creation and social entrepreneurship remains under-developed with few established constructs to allow for specific quantitative testing (Sassmannshausen \& Volkmann, 2018). In addition, applied nature and multidimensionality of relational values and social enterprises require identifying and exploring certain observable patterns. Given the lack of clearly defined social value creation in social entrepreneurship, and somewhat intangible processes of relationally embedded ties, accountability, and their impact, the case study method is most suited for this exploratory study.

$<$ Take in Table 2 about here $>$

\subsection{Sampling Strategy}

We adopted a theoretical sampling approach to select participants in this study. Theoretical sampling is controlled by the emerging theory, whether substantive or formal (Glaser \& Strauss, 2017). Antecedently, a theoretical sampling aims to replicate or extend the emergent theory in case study research (Eisenhardt, 1989; Yin, 2003). Replication logic as theory building has been extensively used in management literature (Gibbert et al. 2016). The criteria used for selecting cases the chosen organizations were: (a) are recognized as successful international social entrepreneurs in the third sector pursuing well-defined social mission goals; (b) operate in different social contexts to allow for analysis of patterns in international social entrepreneurship 
activities; and (c) have been operating for more than five years to ensure that the business model has evolved over time in entrepreneurial pursuits. These criteria resulted in the choice of three organizations (see Table 2) for a multiple case study to corroborate the findings of diverse organizations and different social issues concerning social entrepreneurs.

\subsection{Data Collection}

The data collection process was guided by theory and case study protocol on relevant open-ended questions for in-depth interviews. In addition, qualitative data based on texts, interviews, letters and newspaper articles provided supplementary evidence for the verbal answers. Although the dominant data collection instrument used was interview technique, we also relied on secondary and published data sources about the charity organisations and their international activities. For example, evidence from the interview was supplemented by observation of co-branding between the charity company and its international commercial partners. Multiple data sources enable verification and provide cross-reference for the evidence generated from interviews. Interviews were the primary method used for data collection. The respondents were interviewed at their business premises, and interview answers were digitally recorded with prior consent. Interviews were conducted by one of the researchers involved in this study. Each interview lasted approximately 45 minutes. A total number of 65 interviews have been conducted for this research. The study included interviews with multiple respondents from each case study organization. We used a questionnaire guide in our data collection to ensure reliability. As for external validity, we went back to the charities to validate our main findings. To supplement, the researchers also telephoned and emailed the chosen organizations to collect relevant materials for the 
case study research. Interview data were professionally transcribed and analyzed with reference to other sources of data noted above. The process of transcription involved editing, typing of field notes and correction of recorded interviews.

\subsection{Data Analysis}

Our research aimed to inform international social entrepreneurship literature by exploring the impact of personal relationships on accountability and social value creation processes via CRM practices using a case study method. We started by repeatedly looking at previously published academic research articles and anecdotes to use available knowledge for exploring. During the process, we were looking for meanings inferred by different scholars to the concepts we were trying to investigate and arguments made by us. A closer look on the interpretations made and meanings explained by chosen academic literature presented a gap in the literature. Various perspectives appeared from the review that served as codes during relational analysis because they seemed relevant to the themes we envisaged. Relational analysis allows researchers to perform hermeneutic content analysis, similar to pattern recognition technique used by content analysts (Mohajan, 2018). Consistent with Yin (1994), data analysis for case study research can incorporate multiple techniques such as pattern matching and content analysis. The code labelling guided confirmation of coding categories in support of our own and challenged existing theories used in international social entrepreneurship research. Due to our familiarity with the data from the literature, anecdotes and case under investigation, we could develop a suitable coding structure and re-analyse the case content with a focused approach. Analysing content using codes created from previous literature allowed adoption of a combination of inductive and deductive approaches used in a flexible but rigorous manner. 
Each case study was analyzed individually by one of the researchers involved in this study, and the main findings presented in the next section are based on crosscase analyses. Unlike single case study, cross-case analysis typically allows higher degree of generalizability, while limits the potential of selection biases intrinsic to singular approach. Cross-case analysis has been adopted in exploring various models of social entrepreneurship (Bhushan, 2020 p. 171).

We followed conventional approach of data reduction, data display and conclusion drawing (Miles and Huberman, 1994). Data reduction is the process of selecting, simplifying, abstracting and transforming the data that appear in transcriptions and field notes. The display is an "organized and compressed assembly of information that permits conclusion drawing" (Miles \& Huberman, 1994, p.11). Content analysis, an applicable method for case studies, has been applied to the data (interview transcripts and documents). In exploratory case study research, data analysis encompasses four steps: (1) initial research question, (2) analysis of within case data, (3) search for cross-case patterns, and (4) shaping of propositions (Eisenhardt, 1989).

Just as any goal can only be reached if it is known, exploratory research should be guided by an initial proposition to guide data collection (Yin, 2003). In a second step, within-case data are analyzed, using descriptive accounts and gaining a comprehensive picture of key stakeholder relationships. This goal is to achieve "familiarity with the case as a stand-alone entity" (Eisenhardt, 1989, p. 540). Patton (2002) underscores the importance of meticulous analysis of individual cases. In a third step, cross-case patterns are applied, following a wide-ranging look at the data. Step two and three are linked with each other for a concurrent outlook. With the help of categories or dimensions, within-group differences and similarities can be revealed. Analytic dimensions are based on existing literature (Eisenhardt, 1989). The final step 
of shaping propositions concludes the analytic process. Eisenhardt (1989, p. 541) describes a two-step strategy comprised firstly, of the sharpening of constructs (definitions and evidence building) and secondly, the verification of the emergent relationships between emergent constructs and evidence in each case.

\section{Findings}

$<$ Take in Table 3 about here $>$

Table 3 summarizes the international characteristics and business elements of the three case companies.

\subsection{The role of personal relationships in the exploitation of external resources for social value creation in CRM}

The data analysis revealed that social entrepreneurs operating in international contexts relied on the evolution of relational embeddedness through international alliances for CRM to enhance social value creation. The findings inline with previous studies such as Shane \& Venkataraman, (2000) and Hite, (2005) indicate that international social entrepreneurs generate require relational embeddedness to achieve normative social value. The following subsections of the findings suggest that international social entrepreneurs (1) develop support from personal networks, (2) gain access to resources, (3) implement social activities through ties, (4) share resources, and (5) enhance trust development.

$<$ Take in Table 4 about here $>$ 
The findings of this study support previous studies such as Austin, \& Seitanidi, (2012) by showing that when stakeholders within certain international marketing contexts need greater commitment for CRM activities (e.g. due to customer expectations, competitive strategies, government initiatives etc.), this facilitates CRM-related collaborative initiatives between commercial enterprises and their social enterprise counterparts. The affiliation between commercial and social enterprise generates desired social value that expands CRM initiatives and activities. Specific entrepreneurial human capital is relatively more important in commercial entrepreneurship, and general human capital in social entrepreneurship, and that the effects of human capital depend on the rule of law (Estrin et al., 2016). Thus, for international social entrepreneurs, access to external resources for CRM is facilitated by social mission and altruistic goals of certain stakeholders. Commercial enterprises help to overcome the contextual limitations of implementing social entrepreneurship in international markets characterized by limited availability of supporting institutions and systems. Importantly, our findings show that for international social entrepreneurs, access to resources through personal relationships is crucial for engagement in CRM opportunities with commercial enterprises and eventual achievement of social value for international social entrepreneurs. Inline with Eng et al. (2012), this study explains how resource acquisition through personal relationships enhances market relationship and creates social value that is supplementary to CRM. Personal relationships with networks of commercial enterprises are particularly of value when social enterprises internationalize their operations into new markets and are not able to use their brand advantages due to their limited recognition in these markets. The following quotes (two of the 
international social enterprises) illustrate the significance of developing personal relationships with commercial enterprises in order to access external resources and create opportunities for CRM activities in diverse international markets:

"We wouldn't be able to do like the partnership between Oxfam and Marks and Spencer's because of that type of initiative looking at the major stores like that would have to come from personal recommendations and relationships (Social Charity)".

"Our activity involves developing relationships to raise funds by partnering with other organizations. For example, we work with retailers during seasonal events such as Christmas cards or Easter cards to leverage our social mission for commercial interests. I also look after relationships to develop deals with different manufacturers or retailers... If we had relied solely on growing our services without personal networks and relationships, I would bet that we would be overstretched in terms of resources and our ability to support our activity (Animal Charity)".

$<$ Take in Table 5 about here $>$

As shown in Table 5, personal relationships through CRM-related collaborations of the three case companies have synergistic benefits between international social entrepreneurs and commercial organizations. Regardless of the peculiarities of operating in different international markets, the partners from commercial sectors have the potential to advance the case companies' social mission and objectives. The findings suggest that CRM collaborations have enabled international social enterprises to gain new organizational skills and predominantly supported them to develop new 
capabilities in CRM. In addition, this joint action between commercial and social enterprises generate synergistic outcomes that contribute to social value creation though CRM as well as internationalization of social entrepreneurship. The evidence shows that the role of personal relationship development in synergistic social impact leverages virtual presence, and commercial and government ties (see e.g., Table 6). In specific, personal relationships of social entrepreneurs with external stakeholders influence commercial and governance modalities while maintains CRM oriented social values within their organisations as complimentary resources.

$<$ Take in Table 6 about here $>$

\subsection{The role of personal relationships in the accountability of social entrepreneurship} for social value creation in CRM

Accountability is evident in the international social entrepreneurs through choice and priority of entrepreneurial CRM based ventures that would have the highest potential to produce innovation and generate maximum social impact. The balance of marketing practice and social impact is influenced by institutional environment of the international domain. The international social entrepreneurs illustrated that personal relationships facilitate brokerage of third-party relations by enhancing trust development with new partners for CRM based ventures. CRM based ventures encourages the international social entrepreneurs to undertake complimentary trust building though positive externalities. International social entrepreneurs focus on the social mission, which is central to all activity (Grenier, 2006). Whilst CRM based activities include commercial goals to increase funding or profitability, such goals as well as personal relationships 
of social entrepeneurs do not take precedence over the social mission and goal. These points are elaborated in the following quotes from the respondents:

$<$ Take in Table 7 about here $>$

"For example, the XXXX is a tee-total organization, we don't drink, so we would not be happy entering into a relationship with a company that would be funded by a brewery. We have got to look at each relationship and business proposition on a caseby-case basis and see how we could work together and align our social mission. This may depend on the relationship and the nature of the relationship and what it is there for, so for example if we were receiving donations from such a place we would say no and similarly if they wanted to sponsor an event then we would say no because we don't want to be publicizing what they are doing (Social Charity)".

"I mean we are there to raise the money to provide the service, we don't provide any services that deviate from the same kind of bereavement support (Health Charity)".

"Within our work, we maintain our focus on animal welfare rather than share whatever opportunities that we come across (Animal Charity)".

Trust-based relationships between the international social entrepreneurs and different stakeholders are characterized by co-evolution in terms of commitment of resources over time and mutual understanding. Such relationships enable the development of reciprocal support between not only the social entrepreneurs but also the international 
social enterprises and their partners to achieve social goals. In an international social entrepreneurship context, social entrepeneurs engage with their external stakeholders or partners to supplement their resource allocation through trust-building and sharing. Trust building has been particularly important when operating in contexts with high degree of regulatory protection and sanctions against potential harms from deceptive CRM practices. From a commercial enterprise perspective, CRM activities constitute risky undertakings, which may influence a firm's reputation in the market. As such, commercial enterprises prefer to work with international social entrepreneurs which are perceived to be familiar and trustworthy in meeting the requirements of CRM undertakings. From an international social entrepreneur perspective, it is important to collaborate with commercial entrepreneurs which are not constrained by a sense of social responsibility but are genuinely interested to create social value through CRM. Thus, in the context of international social entrepreneurship, the development and maintenance of trust through accumulation of social capital through personal relationships is seen as central to developing and sustaining organisational relationships, and implementing effective CRM activities. This, in turn, generates higher degree of assimilation of social value by means of social capital through personal relationships. It has also been found that trust heightens the accountability in CRM through international social entrepreneurship in which personal relationships help create social value. The developed accountability ignores non-residual financial gain and maximizes social welfare. This also indicates that conflicting economic and social logics can be mitigated, given that accountability is strengthened through cumulative social value creation of individual social entrepreneurs. As emphasized by the three case companies: 
"We actually run the conference (associated with their CRM campaign) so that they work in small groups, but the groups change so they get to know everybody, and we now involve assistant managers as well as the managers to network across a larger group of people. But they don't ring every other manager but rather tend to rely on trust developed between business partners over time (Social Charity)".

"I mean in the XXX industry you may get offers to do calendars and things for you or within the XXX industry, but we must have mutual interests and support each other's goals. It is also very important to know our business partners personally, because the majority of our income depends on their continued support, donations and introduction to new markets or customers (Animal Charity)".

A crucial aspect for long-term collaborations with respect to CRM activities relates to the ability of international social entrepreneurs in aligning their social goals with the strategic goals of the commercial enterprises. For example, they need to be responsive to the differing needs of their commercial enterprise partners' customers. This includes being proactive to anticipate and plan how to deliver social value to satisfy future needs of customers from different markets. It is through clear communications and knowledge of diverse international markets in personal relationships that international social entrepreneurs are able to understand social benefits of alliances for commercial partners and their customers. The motivational factors of social entrepreneurs to understand the benefits of commercial partners originate from the relational ties that specifies a set of social value. These excerpts from the data analysis illustrate international social entrepreneur obligations: 
"Many of our local networks have existed for over ten years and through existing links we develop partnerships to respond to local needs (social value). But having said that it is very easy to become blind to local needs because you are looking at what is immediately in front of you rather than beyond what we've got to deliver in the future. We use knowledge of markets through research to identify our key partners and customers. I think over the years we have responded well especially working with existing links to improve standards of living (Social Charity)".

"We have put together a number of things locally, involving local associations, traders, retailers, and other interest groups. We make sure that we have regular conversation with all of them and all of us can benefit from these relationships. It is our goal to communicate with our target stakeholders clearly and build understanding for ways to improve customer satisfaction (Health Charity)".

The notion of relationship brokering in social entrepreneurship is not merely concerned with exploiting new resources or non-redundant resources in networks (Burt, 1992). However, weak ties in relational embeddedness can be facilitated by personal relationships. The strategic CRM based collaborations between the international social entrepreneurs and external stakeholders such as major retailers may depend on elements of personal support for social goals between the partners.

In addition, innovation featured strongly in accountability of the international social entrepreneurs such as through strategic collaborations described above. A majority of innovation outcomes noted by the international social entrepreneurs are derived from personal relationships acting as bridges to leverage network resources within relationally embedded ties. Innovation driven alliances creates critical 
consolidation of relational ties between social entrepreneurs and their external stakeholders, and stimulates social values. While this type of innovation can be described as combining innovations between social and commercial ventures to create social change (Perrini and Vurro, 2006), the international social entrepreneurs stressed social mission as their underpinning leverage for mobilizing under-utilized resources and sharing resources with commercial partners. This emphasis realizes and communicates the social goals of the international social entrepreneurs during CRMrelated collaborations without deviating and/or antagonizing stakeholders of charitable interests.

"Individual Directors of Business in each of those divisions would ensure that all of those guidelines [Ethical Guidelines] are fulfilled and if they need to be reviewed then they may come to some kind of ad hoc group here that would review them. We may have partnered with commercial retailers but our core values wouldn't change and we make sure our brand or presence has impact for what we stand for (Social Charity)".

“Our mission statement is to give specialist services to terminally ill patients. While we do fundraising activities to support this cause, we are conscious of the need to give a bereavement service to people who have lost loved ones or relatives. This is another part of what the hospice does so we are serving the hospice mission statement in that respect - but there is no other way really in which we can support our charity other than to raise money for it and partner with other organizations to support this mission (Health Charity)". 
“There are some companies that we probably wouldn't want to work with. As long as they were reputable and if it's a new company that we are working with, such as a manufacturer, then we would probably look to see they have been in existence for at least three years and if they had published accounts for about three years and they seemed okay then we would usually work with them as long as they weren't doing anything that we disagreed with ethically or against our social mission. There are a number of companies that we don't work with, but you would need to talk to somebody else to get that full list (Animal)".

A distinct characteristic of the type of innovation created by the international social entrepreneurs is that the execution and implementation of social and entrepreneurial activities depend more on personal relationships or formation of strategic collaborations rather than direct ownerships for implementation of innovation. While it has been noted that social entrepreneurs need not be inventors, but rather effective implementers of innovations (Martin, 2004), there is evidence that competent international social entrepreneurs are able to orchestrate the implementation of innovations through personal ties without possessing the resources to innovate. Such entrepreneurial pursuits tend to exploit accountability of the social mission of non-profit organizations while proactively contribute to the development of CRM-related activities with commercial organizations.

"We all meet, I mean we have networking lunches and we have conferences and we get various people involved in those but one of the things I am very disappointed to say is that very few charities will reveal very easily especially who support them and who they know, personally. I think we are so focused on delivering a business plan 
ourselves we feel that if we share too much about our networks and ideas, we would not be able to implement what we want to do through personal networks (Social Charity)".

"We are also members of the XXX which we attend and develop relationships. There are various committees, which generally help share information between all of the charities. For example, we got a recycling group to do with how we source our goods and then how we make the most of what we have,,, so I actually go to all of those meetings to network with colleagues from other charities in some respects especially to think of new ways to market ourselves (Health Charity)".

4.3. The role of accountability through relationally embedded in social value creation during CRM

The international social entrepreneurs increase their social impact through the elements of trust, goal congruence, working in partnership and quality of social activities in relationally embedded ties within international markets. The social impact creates other-regarding values those are central to the mission of social value. Acknowledging heterogeneity within international context, social value creation becomes conduit to relational ties. Social value creation draws on the social capital of network ties by combining, brokering and leveraging network resources to exploit CRM opportunity and respond to changes in the environment. In this sense, social value creation means mobilizing relational embeddedness as stocks of valuable resources developed over time and evolved among personal relationships.

The findings from the case companies suggest that social value creation in CRM through international social entrepreneurship is rather holistic and encompasses 
different time spans, in which social capital may be residing in international networks but may be mobilized in the future. Key discerning aspects of social value creation in CRM from the data include accountability, with spill-over commercial effects from social mission of the international social entrepreneurs leading to innovation and synergistic collaboration with both non-profit and commercial entities in diverse markets. The outcomes and social impact include social change with international reach in terms of pursuing the social mission of the case companies (see Table 8). As such, measurement of social value creation is less concerned with financial returns but more about social return on investment (cf. Clark et al., 2003). For example, improvements related to standards of living, animals' welfare and health services are major social objectives of the international social entrepreneurs in this study. Similarly, international social entrepreneurs monitor operational performance by focusing on accountability such as quality assurance scheme, responsiveness and ongoing assessment of social impacts in CRM. While social capital in networks presents commercial opportunities and potential conflicts of interest with non-profit goals, the choice of partners and access to resources through personal relationships is motivated and influenced by the social mission. In synergistic relationships with commercial partners, the social impact is far-reaching in terms of achieving both sharing of social mission and fulfilling financial objectives. Thus, international social entrepreneurs may proactively combine, broker and leverage their international social networks to establish partnerships and create social value.

$<$ Take in Table 8 about here $>$

$<$ Take in Table 9 about here $>$ 
The findings reveal that accountability in CRM provides a means for strengthening social mission of the case companies as social entrepreneurs in an international context. While international social entrepreneurs may have diverse or different organizational interests, knowledge and understanding of social mission in terms of accountability in CRM would help the development of international social entrepreneurship goals and value creation. It is a key element for aligning potentially conflicting interests especially with commercial partners, as social value could be developed and/or assessed in different forms, not necessarily through financial goals.

\section{Discussion and Implications}

\subsection{Discussion}

This knowledge of commercial activities may potentially impinge on the social mission. This can be linked to competence-based trust, implying the ability to mobilize trust relations to achieve social goals for CRM and create social impact. The social elements of loyalty, goal congruence and communication quality are most pertinent in the utilization of trust-based personal relationships to access international network resources for CRM. In particular, international social entrepreneurs may be relying on partners to implement relevant CRM activities such as development and introduction of new products through strategic alliances. Thus:

Proposition 1: In international social entrepreneurship, the impact of personal relationships in relationally embedded ties on social value creation in CRM is facilitated by competence-based trust to achieve goal congruence.

Given the significance of accountability in international social entrepreneurship for CRM, there are limits as regards the extent to which network resources can be 
leveraged for business performance. Research on network resources would need to qualify that whilst there are clear opportunities in networks, social entrepreneurs must observe their core social principles to continue leveraging international resources for potentially conflicting charity and social goals, and stakeholders' interests. Apart from the social components identified for accessing international network resources for CRM mainly through personal relations, aligning common goals and paths between partners with the accountability of social mission is an overriding strategic decision for exploiting network ties. For example, mutual benefits (synergistic partnerships) for CRM activities featured strongly in the development of international strategic alliances with commercial interests especially for brokered ties or indirect ties. Moreover, social entrepreneurs would have limited resources to implement international social initiatives or would have to rely on personal goodwill. The latter would entail an assessment of accountable actions to reduce any negative perceived impact for commercial organizations from aligning with the charity's social mission. It can be argued that international social entrepreneurship can generate social impact or create social value through CRM beyond commercially oriented organizations. This aspect of relationally embedded ties is not so much about exploiting personal ties but aligning social interests to create new CRM opportunities, as evidenced by social change and innovation. Theoretically, this study advances:

Proposition 2: In international social entrepreneurship, personal ties that align with accountability of social entrepreneurs are more likely to evolve to embedded ties that lead to social value creation in CRM.

Network relationships are dynamic and constantly evolve through action on the part of a firm, or inaction with changes in the network. The significance of relationally embedded ties cannot be over-emphasized in terms of social value creation. The 
differences between social entrepreneurship and commercial entities suggest that social value may be the result of sustained CRM activities over time rather than tangible shortterm results, e.g., health care improvement and climate protection. The social impact would not be bound to one organization but would need to involve coordinated efforts of various organizations. The extensive impact of social value created in the environment can be described as non-sticky competence. Relationally embedded ties have been shown to provide a means for social entrepreneurs to link their CRM activity to social value creation on international levels. A major component of relationally embedded ties is social capital residing in the social entrepreneur's international networks of relationships, in and through personal ties where social entrepreneurs can mobilize international network resources to create social value through CRM. In some respect the social capital represents goodwill and trust to be mobilized and deployed through CRM activities and marketization mechanisms. However, the complexity of interactions, noise in communications, goal differences and blurring the boundary of international networks would further impair the clarity for accounting specific contributions in social value measurement. Thus:

Proposition 3: In international social entrepreneurship, social entrepreneurs capable of orchestrating, combining and leveraging (both accountability and network resources) in relationally embedded ties are more likely to demonstrate strong social impact and social value creation in CRM.

\subsection{Theoretical Implications}

Past studies on entrepreneurial networks and network ties have examined the role of relational embeddedness and structural characteristics for the discovery of opportunities and mobilization of resources (e.g., Shane \& Venkataraman, 2000; Hite, 2005; Burt, 
1992). This study builds on this knowledge, focusing on the role of personal relationships to understand the processes in which international social entrepreneurs exploit external resources to enhance social value creation in CRM. The main difference for the purpose of engaging in CRM between social entrepreneurs and commercial entrepreneurs is the obligation of social mission to fulfil charity goals and satisfy non-profit stakeholder needs. This distinction is captured by the concept of accountability. While literature on non-profit organizations recognizes the significance of social networks for collaboration, partnership, marketing and innovation (e.g., Perrini \& Vurro, 2006; Mair \& Schoen, 2005), little is known about how accountability of social entrepreneurship for CRM in relationally embedded ties impacts on social value creation especially in international partnerships. Further, the international alliances of social entrepreneurs are less studied with reference to CRM where social value attributes are evaluated by embedded relational ties. Research about the role of personal relationships for CRM would fill an important gap in the literature concerning the impact on social value creation through processes of relationally embedded ties. Future research can also consider additional factors such as gender and cultural capital issues to investigate the role of personal relationships of international social entrepreneurs in the accountability and social value creation of non-profit organisations.

\subsection{Managerial Implications}

A common theme emerged that personal relationships permeate relationally embedded ties beyond dyadic interactions, such as access to non-directly connected personal relationships. Personal relationships may be characterized by mutual trust, co-evolution and principles of altruism, which are not necessarily driven by financial or commercial objectives. The need to fulfil social objectives, missions and obligations are central to 
the involvement of international social entrepreneurs in CRM activities with commercial organizations. Accountability through clear communications serves as the basis for brokering new ties or partnerships within the social relations of entrepreneurs, particularly weak ties rendering trust for third party endorsement and sharing of information. Although partnerships with commercial organizations may create social value in CRM, the reliance on personal relationships may expose international social entrepreneurs to unethical practice beyond immediate relationships and/or opportunistic behavior without formal contracting mechanisms. International social entrepreneurs must therefore match the core values of their social mission with potential partners in their CRM engagements.

\section{Conclusion}

This study examined how social entrepreneurs mobilize personal relationships to create social value in the context of international social entrepreneurship. While it may be difficult to apply the same principles of measuring value creation of commercial organizations to social entrepreneurs, further research could examine the propositions and develop metrics with the view of accounting for the nature of value creation through network ties in international social entrepreneurship. Specifically, accountability is a key characteristic of international social enterprises, which has implications for choice of personal ties, subsequent exploitation of external relationship-based resources and eventual social value creation. Social entrepreneurs possess altruistic needs of the social mission that may override choice of commercial alliances, activities and/or profitmaking pursuits. As such, personal relations play a key role in aligning social mission with other commercial interests. This requires accountable actions in terms of value creation and governance of international partners. The main managerial implications 
include quality of communications, knowledge of the market and goal congruence in relationally embedded ties in international markets. As far as internationalization is concerned, personal ties may act as conduits to reach non-directly connected relationships for combining social and commercial interests. The use of personal relationships eliminates some of the costs associated with formal contracting mechanisms and enhances trust to access international network resources. In the context of international social entrepreneurship, more research is needed to establish the role of personal relationships in competence-based trust in combining, brokering and leveraging network ties to enhance social value creation. Further research could examine the role of trust in creating greater social value from a social entrepreneurial perspective rather than from a solely non-profit social mission.

\section{References}

Adam, C., \& Perlmutter, F. (1991). Commercial venturing and the transformation of America's voluntary social welfare agencies. Nonprofit and Voluntary Sector Quarterly, 20(1), 25-38. 
Aguilera, R. V., \& Crespi-Cladera, R. (2016). Global corporate governance: On the relevance of firms' ownership structure. Journal of World Business, 51(1), 50-57.

Aguinis, H., \& Glavas, A. (2012). What we know and don't know about corporate social responsibility: A review and research agenda. Journal of Management, 38, $932-968$.

Alter, K. S. (2007). Social Enterprise Typology [Online] Virtue Ventures LLC. Available from: http://www.virtueventures.com/setypology/ (Accessed 1 March 2007).

Arslan, A., Golgeci, I., Haapanen, L., Tarba, S., Cooper, C. \& Degbey, W.Y. (2020). Cause-related marketing, legitimacy and internationalization of professional service firms: A case study of a football talent scouting microfirm. International Marketing Review, ahead-of-print. https://doi.org/10.1108/IMR-05-2019-0143.

Arya, B., \& Salk, J. E. (2006). Cross-sector alliance learning and effectiveness of voluntary codes of corporate social responsibility. Business Ethics Quarterly, $16(2), 211-234$.

Aswo, S., \& Gerald, A. (2019). Transactional or relational exchange theory in B2C marketing: An agenda for a different type of relational exchange theory. Journal of customer Behaviours, 18(2), 87-100.

Austin, J. E. (2000). Strategic collaboration between nonprofits and business. Nonprofit and Voluntary Sector Quarterly, 29(1), 69-79. 
Austin, J. E. (2006). Avenues for social entrepreneurship research. In: Mair, J., Robinson, J., \& Hockerts, K. (eds.) Social Entrepreneurship. 22-33, Basingstoke: Palgrave Macmillan.

Austin, J., Stevenson, H., \& Wei-Skillern, J. (2006). Social and Commercial Entrepreneurship: Same, Different or Both? Entrepreneurship, Theory \& Practice, 30(1), 1-22.

Austin, J.E., \& Seitanidi, M.M. (2012). Collaborative value creation: A review of partnering between nonprofits and businesses: Part 1: Value creation spectrum and collaboration stages. Nonprofit and Voluntary Sector Quarterly, 41(5), 726-758.

Bacq, S., \& Eddleston, K.A. (2018). A Resource-Based View of Social Entrepreneurship: How Stewardship Culture Benefits Scale of Social Impact. Journal of Business Ethics, 152, 589-611.

Bagnoli, L., \& Megali, C. (2011). Measuring performance in social enterprises. Nonprofit and Voluntary Sector Quarterly, 40(1), 149-165.

Barman, E. (2015). Of principle and principal: Value plurality in the market of impact investing. Valuation Studies, 3(1), 9-44.

Bates, T. (1997). Financing Small Business Creation : The Case of Chinese and Korean Immigrant Entrepreneurs. Journal of Business Venturing, 12(2), 109-124.

Benjamin, L.M. (2012). The potential of outcome measurement for strengthening nonprofits' accountability to beneficiaries. Nonprofit and Voluntary Sector Quarterly, 42(6), 1224-1244.

Bhushan B. (2020). Motivational Model of Social Entrepreneurship: Exploring the Shaping of Engagement of Social Entrepreneur. In: Majumdar S., Reji E. (eds) 
Methodological Issues in Social Entrepreneurship Knowledge and Practice. Springer Proceedings in Business and Economics. Springer, Singapore.

Bianchi, M. , Chiaroni, D., Chiesa, V., \& Federico Frattini. (2011). Exploring the role of human resources in technology out-licensing: an empirical analysis of biotech New technology-based firms. Technology Analysis \& Strategic Management, 23(8), 825-849.

Bonner, J.M., \& Walker, O.C. (2004). Selecting influential business-to-business customers in new product development: Relational embeddedness and knowledge heterogeneity considerations. Journal of Product Innovation Management, 21(3), 155-169.

Bonnstetter, B.J. (2012). New research: The skills that make an entrepreneur. Harvard Business Review, December, https://hbr.org/2012/12/new-research-the-kills-that$\underline{\mathrm{m}}$.

Bornstein, D. (2007). How to change the World. Social Entrepreneurs and the Power of new Ideas. Oxford: Oxford University Press.

Boschee, J. (1995). Social entrepreneurship. Across the Board, 32(2), 20-23. EBSCO Host [Online]. Available from: http://search.ebscohost.com/login.aspx?direct=true $\& d b=$ buh\&AN=9503071971 $\&$ site $=$ ehost-live (Accessed 10 March 2008).

Bourdieu, P. (1997). What makes a social class? On the theoretical and practical existence of groups. Berkeley Journal of Sociology, 32, 1-17.

Brooks, A. C. (2009). Social Entrepreneurship: A Modern Approach to Social Venture Creation. London: Pearson International. 
Burga, R., \& Rezania, D. (2015). A Scoping Review of Accountability in Social Entrepreneurship. SAGE Open. doi: 10.1177/2158244015614606.

Burt, R.S. (1992). Structural holes: The social structure of competition. Cambridge, MA: Harvard University Press.

Caldwell, N.D., Roehrich, J.K., \& George, G. (2017). Social Value Creation and Relational Coordination in Public-Private Collaborations. Journal of Management Studies, 54(1), 906-928.

Carney, M., Dieleman, M., \& Taussig, M. (2016). How are institutional capabilities transferred across borders? Journal of World Business, 51(6), 882-894.

Chang, K. H., \& Gotcher, D. F. (2007). Safeguarding investments and creation of transaction value in asymmetric international subcontracting relationships: The role of relationship learning and relational capital. Journal of World Business, 42(4), 477-488.

Chell, E., Nicolopoulou, K., \& Karatas-Ozkan, M. (2010). Social entrepreneurship and enterprise: International and innovation perspectives. Entrepreneurship \& Regional Development, 22(6), 485-493.

Choi, N. and Majumdar, S. (2014). Social entrepreneurship as an essentially contested concept: opening a new avenue for systematic future research. Journal of Business Venturing, 29, 363-376.

Christensen, L. J., Mackey, A., \& Whetten, D. (2014). Taking responsibility for corporate social responsibility: The role of leaders in creating, implementing, sustaining, or avoiding socially responsible firm behaviors. The Academy of management Perspectives, 28(2), 164-178. 
Clark, C., Rosenzweig, W., Long, D., \& Olsen, S. (2003). Double Bottom Line Project Report: Assessing Social Impact In Double Bottom Line Ventures. Methods Catalog [Online] RISE Project, Columbia Business School. Available from: http://www.riseproject.org/DBL_Methods_Catalog.pdf (Accessed: 23 September 2007).

Czinkota, M. (2017) The soul of business, Qualitative Market Research: An International Journal, 20(2), 226-229,

Czinkota, M. R., \& Ronkainen, I. A. (2005). A forecast of globalization, international business and trade: report from a Delphi study. Journal of World Business, 40(2), 111-123.

Danis, W. M. (2003). Differences in values, practices, and systems among Hungarian managers and Western expatriates: An organizing framework and typology. Journal of World Business, 38(3), 224-244.

Dees, G. (1998). The Meaning of "Social Entrepreneurship" [Online] Center for the Advancement of Social Entrepreneurship. Duke University. The Fuqua School of $\begin{array}{lll}\text { Business. } & \text { Available from: }\end{array}$ http://www.fuqua.duke.edu/centers/case/documents/dees_SE.pdf (Accessed 2 April 2007).

Dees, J.G. (1998). Enterprising non-profits. Harvard Business Review, 76, 54-69.

Desa, G. (2012). Resource Mobilization in International Social Entrepreneurship: Bricolage as a Mechanism of Institutional Transformation. Entrepreneurship Theory and Practice, 36(4), 727-751.

Desa, G., \& Basu, S. (2013). Optimization Versus Bricolage in Global Social Entrepreneurship. Strategic Entrepreneurship Journal, 7(2), 26-49. 
Doern, R. R., \& Fey, C. F. (2006). E-commerce developments and strategies for value creation: The case of Russia. Journal of World Business, 41(4), 315-327.

Doherty, B., Haugh, H., \& Lyon, F. (2014). Social enterprises as hybrid organizations: A review and research agenda. International Journal of Management Reviews, $16(4), 417-436$.

Domurath, A., \& Patzelt, H. (2016). Entrepreneurs' Assessments of Early International Entry: The Role of Foreign Social Ties, Venture Absorptive Capacity, and Generalized Trust in Others. Entrepreneurship Theory and Practice, 40(5), 1149-1177.

Eberhard, M., \& Craig, J. (2013). The evolving role of organisational and personal networks in international market venturing. Journal of World Business, 48(3), 385397.

Eisenhardt, K. M. (1989). Building theories from case study research. Academy of Management Review, 14(4), 532-550.

Elkington, J. (2004). Enter the triple bottom line. In: Henriques, A. \& Richardson, J. (eds.) The Triple Bottom Line: Does it all add up? Assessing the Sustainability of Business and CSR, 1-16, Earthscan.

Eng, T.Y., Liu, C-Y. G., \& Sekhon, Y.K. (2012). Examining the Role of RelationallyEmbedded Networks in Resource Acquisition of British Nonprofit Organizations. Nonprofit and Voluntary Sector Quarterly, 41(6), December, 1093-1116.

Estrin, S., Mickiewicz, T. and Stephan, U. (2016). Human capital in social and commercial entrepreneurship, Journal of Business Venturing, 31(4), 449-467. 
Eteokleous, P. P., Leonidou, L. C. and Katsikeas, C. S. (2016). Corporate social responsibility in international marketing: Review, assessment, and future research. International Marketing Review, 33 (4), 580-624.

Ferguson, A. M. (2018). Building theory in public relations: Interorganizational relationships as a public relations paradigm, Journal of Public Relations Research, 30(4),164-178.

Gartner, W. B. (1985). A conceptual framework for describing the phenomenon of new venture creation. Academy of Management Review, 10(4), 696-706.

Gibbert, M., N. B. Lakshmi, \& Ruigrok, W. (2016). What passes as rigorous replication logic in management case study research? Academy of Management Proceedings.

Glaser, B. G., \& Strauss, A. L. (2017). Theoretical sampling. In Sociological Methods, Routledge.

Gnyawali, D.R., \& Fogel, D.S. (1994). Environments for entrepreneurship development: Key dimension. Entrepreneurship Theory \& Practice, 18(4), 43-63.

Granovetter, M.S. (1985). Economic action and social structure: The problem of embeddedness. American Journal of Sociology, 91(3), 481-510.

Granovetter, M.S. (1992). Problems of explanation in economic sociology. In Nohria, N. \& Eccles, R. (eds.), Networks and Organizations, 25-56. Boston: Harvard Business School Press.

Grenier, P. (2006). Social entrepreneurship: agency in a globalizing World. In: Nicholls, A. (ed.), Social Entrepreneurship: New Models of Sustainable Social Change, 119-143. Oxford: Oxford University Press. 
Grieco, C., Michelini, L., \& Iasevoli, G. (2014). Measuring value creation in social enterprises: A cluster analysis of social impact assessment models. Nonprofit and Voluntary Sector Quarterly, 44(6), 1173-1193

Gulati, R. (1995). Does familiarity breed trust? The implications of repeated ties for contractual choice in alliances. Academy of Management Journal, 38(1), 85-112.

Hite, J. M. (2005). Evolutionary processes and paths of relationally embedded network ties in emerging entrepreneurial firms. Entrepreneurship Theory \& Practice, 29(1), 113-144.

Hite, J. M., \& Hesterly, W. S. (2001). The evolution of firm networks: From emergence to early growth of the firm. Strategic Management Journal, 22(3), 275286.

Hlady-Rispal, M. and Servantie, V. (2016). Business models impacting social change in violent and poverty-stricken neighbourhoods: a case study in Colombia. International Small Business Journal, 35(4), 427-448.

Hong, J. F., \& Nguyen, T. V. (2009). Knowledge embeddedness and the transfer mechanisms in multinational corporations. Journal of World Business, 44(4), 347356.

Jenson J. (2017). Modernising the European Social Paradigm: Social Investments and Social Entrepreneurs. Journal of Social Policy, 46(1), 31-47.

Kaplan, R. S. (2001). Strategic performance measurement and management in nonprofit Organizations. Nonprofit Management \& Leadership, 11(3), 353-370.

Kearns, K.P. (1996). Managing for accountability: Preserving the public trust in public and non-profit organizations. San Francisco: Jossey-Bass. 
Kelley, T. (2009). Law and choice of entity on the social enterprise frontier. 84 Tulane Law Review, 337, 363-64

Kiessling, T., Harvey, M., \& Moeller, M. (2012). Supply-chain corporate venturing through acquisition: Key management team retention. Journal of World Business, 47(1), 81-92.

Kissane, R. J., \& Gingerich, J. (2004). Do you see what I see? Nonprofit and resident perceptions of urban neighborhood problems. Nonprofit and Voluntary Sector Quarterly, 33(2), 311-333.

Kolk, A. (2016). The social responsibility of international business: From ethics and the environment to CSR and sustainable development. Journal of World Business, 51(1), 23-34.

Kraus, S., Filser, M., \& O’Dwyer, M. (2014). Social Entrepreneurship: An exploratory citation analysis. Review of Management Science, 8, 275-292.

Leavitt, K., Reynolds, S. J., Barnes, C. M., Schilpzand, P., \& Hannah, S. T. (2012). Different Hats, Different Obligations: Plural Occupational Identities and Situated Moral Judgments. Academy of management Journal, 55(3), 1316-1333.

Lepoutre, J., Justo, R., \& Terjesen, S. (2013). Designing a global standardized methodology for measuring social entrepreneurship activity: The Global Entrepreneurship Monitor social entrepreneurship study. Journal of Small Business Economics, 40(5), 693-714. 
Levin, D. Z. and Cross, R. (2004) The Strength of Weak Ties You Can Trust: The Mediating Role of Trust in Effective Knowledge Transfer, Management Science, 50(11), 1477-1490.

Levin, D. Z., \& Cross, R. (2004). The strength of weak ties you can trust: The mediating role of trust in effective knowledge transfer. Management Science, $50(1), 1477-1490$.

Li, Y., Wang, X., Huang, L., \& Bai, X. (2013). How does entrepreneurs' social capital hinder new business development? A relational embeddedness perspective, Journal of Business Research, 66(12), 2418-2424.

Liket, K. C., \& Maas, K. (2015). Nonprofit organizational effectiveness: Analysis of best practices. Nonprofit and Voluntary Sector Quarterly, 44(2), 268-296.

Liu, C. L. E., Ghauri, P. N., \& Sinkovics, R. R. (2010). Understanding the impact of relational capital and organizational learning on alliance outcomes. Journal of World Business, 45(3), 237-249.

Liu, C-Y. G., Eng, T. Y., \& Ko, W-W. (2013). Strategic direction of corporate community involvement. Journal of Business Ethics, 115(3), 469-487.

Luke, B., Barraket, J., \& Eversole, R. (2013). Measurement as legitimacy versus legitimacy of measures: Performance evaluation of social enterprise. Qualitative Research in Accounting \& Management, 10(3/4), 234-258.

Maas, K., \& Liket, K., 2011. Social impact measurement: a classification of methods. In: R. L. Burritt, S. Schaltegger, M. Bennett, T. Pohjola, \& M. Csutora (Eds.), Environmental management accounting and supply chain management (pp. 171202). Dordrecht: Springer Netherlands. 
Mair, J., \& Martí, I. (2006). Social entrepreneurship research: A source of explanation, prediction, and delight. Journal of World Business, 41 (1), 36-44.

Mair, J., \& Noboa, E. (2005). How intentions to create a social venture are formed: a case study. Barcelona: IESE Business School Working Paper No. 593.

Mair, J., \& Schoen, O. (2005). Social entrepreneurial business models: An exploratory study. Working Paper No. 610 [Online]. Barcelona: IESE Business School, University of Navarra. Available from: http://ssrn.com/abstract=875816 (Accessed 11 August 2007).

Manning, K., Birley, S., \& Norburn, D. (1989). Developing a new ventures strategy. Entrepreneurship Theory \& Practice, 14(1), 68-80.

Martin, M. (2004). Surveying social entrepreneurship: Toward an empirical analysis of the performance revolution in the social sector. Arbeitspapiere Band 2. University of St. Gallen [Online]. Available from: http://www.cse.unisg.ch/download.php?file_id=230 (Accessed 1 December 2007).

Martin, R., \& Osberg, S. (2015). Two keys to sustainable social enterprise, Harvard Business Review, May.

Miles, M. B., \& Huberman, M. (1994). Qualitative Data Analysis. Newbury Park, CA: Sage.

Mitchell, R. K., Weaver, G. R., Agle, B. R., Bailey, A. D., \& Carlson, J. (2016). Stakeholder agency and social welfare: Pluralism and decision making in the multiobjective corporation. Academy of Management Review, 41(2), 252-275. 
Mohajan, H. K. (2018). Qualitative research methodology in social sciences and related subjects. Journal of Economic Development, Environment and People, 7(1), 23-48.

Moizer, J., \& Tracey, P. (2010), Strategy making in social enterprise: The role of resource allocation and its effects on organizational sustainability. Journal of System Research, 27, 252-266.

Molecke, G., \& Pinkse, J. (2017). Accountability for social impact: A bricolage perspective on impact measurement in social enterprises. Journal of Business Venturing, 32(5), 550-568.

Morgeson, F. P., Aguinis, H., Waldman, D. A., \& Siegel, D. S. (2013). Extending corporate social responsibility research to the human resource management and organizational behaviour domains: A look to the future. Personnel Psychology, $66,805-824$.

Musteen, M., Francis, J., \& Datta, D. K. (2010). The influence of international networks on internationalization speed and performance: A study of Czech SMEs. Journal of World Business, 45(3), 197-205.

Nahapiet, J., \& Ghoshal, S. (1998). Social capital, intellectual capital, and the organizational advantage. Academy of Management Review, 23(2), 242-266.

Nandan, M., Singh, A., \& Mandayam, G. (2019). Social Value Creation and Social Innovation by Human Service Professionals: Evidence from Missouri, USA. Administrative Science, 9(4), 86-112.

Nicholls, A. (2006). Social Entrepreneurship: New Models of Sustainable Social Change. Oxford: Oxford University Press. 
Ospina, S., Diaz, W., \& O’Sullivan, J. F. (2002). Negotiating accountability: Managerial lessons from identity-based nonprofit organizations. Nonprofit and Voluntary Sector Quarterly, 31(1), 5-31.

Parente, C., Santos, M., Marcos, V., Costa, D., \& Veloso, L. (2012). Perspectives of social entrepreneurship in Portugal: Comparison and contrast with international theoretical approaches. International Review of Social Research, 2(2), 103-124.

Park, B. I., \& Ghauri, P. N. (2015). Determinants influencing CSR practices in small and medium sized MNE subsidiaries: A stakeholder perspective. Journal of World Business, 50(1), 192-204.

Paton, R. (2008). Managing and measuring social enterprises, London: Sage Publications.

Peredo, A. M., \& McLean, M. (2006). Social entrepreneurship: A critical review of the concept. Journal of Business Development, 41(1), 56-65,

Perrini, F., \& Vurro, C. (2006). Social entrepreneurship: Innovation and social change across theory and practice. In: J. Mair, J. Robinson, \& K. Hockerts (eds.) Social Entrepreneurship, 57-85, Basingstoke: Palgrave Macmillan.

Porter M.E., \& Kramer M.R. (2019) Creating Shared Value. In: Lenssen G., Smith N. (eds) Managing Sustainable Business. Springer, Dordrecht.

Portes, A., \& Sensenbrenner, J. (1993). Embeddedness and immigration : Notes on the social determinants of economic action. American Journal of Sociology, 98(6), 1320-1350.

Quinn Patton, M. (2002). Qualitative Research and Evaluation Methods. 3rd ed. Thousand Oaks: Sage. 
Ramus, T., \& Vaccaro, A. (2017). Stakeholders matter: How social enterprises address mission drift. Journal of Business Ethics, 143(2), 307-322.

Ridley-Duff, R., \& Bull, M. (2011). Understanding social enterprise: Theory and practice, London; Sage Publications.

Rinaldo, H. (2010). Getting started in social impact measurement: A guide to choosing how to measure social impact. Norwich: The Guild. Retrieved from http://www.socialauditnetwork.org.uk/files/8113/4996/6882/Getting_started_in_ social_impact_measurement_-_270212.pdf

Rowley, T., Behrens, D., \& Krackhardt, D. (2000). Redundant governance structures: An analysis of structural and relational embeddedness in the steel and semiconductor industries. Strategic Management Journal, 21(3), 369-386.

Sagawa, S., \& Segal, E. (2000). Common interest, common good: Creating value through business and social sector partnerships. California Management Review 42(2), 105-122.

Sassmannshausen, S. P., \& Volkmann, C. (2018). The Scientometrics of Social Entrepreneurship and Its Establishment as an Academic Field. Journal of Small Business Management, 56(2), 251-273.

Schaltegger, S., \& Wagner, M. (2011). Sustainable entrepreneurship and sustainability innovation: categories and interactions. Business strategy and the environment, $20(4), 222-237$.

Schiller, R. S., \& Almog-Bar, M. (2013). Revisiting collaborations between nonprofits and businesses: An NPO-centric view and typology. Nonprofit and Voluntary Sector Quarterly, 42(5), 942-962. 
Seham G., Tolba A, \& Ismail, I. (2017) What motivates social entrepreneurs to start social ventures?: An exploratory study in the context of a developing economy. Social Enterprise Journal, 13(3), 268-298.

Shane, S., \& Venkataraman, S. (2000). The promise of entrepreneurship as a field of research. Academy of Management Review, 25(1), 217-227.

Spear, R. (2006). Social entrepreneurship: A different model. International Journal of Social Economics, 33(5/6), 399-410.

Thompson, J. L. (2002). The world of the social entrepreneur. The International Journal of Public Sector Management, 15(5), 412-431.

Thompson, J. L., Alvy, G., \& Lees, A. (2000). Social entrepreneurship - a new look at the people and the potential. Management Decision, 38(5), 328-338.

Tukamushaba, E.K., Orobia, L. \& George, B.P. (2011). Development of a conceptual model to understand international social entrepreneurship and its application in the Ugandan context. Journal of International Entrepreneurship, 9(7), 282-298.

Uzzi, B. (1997). Social structure and competition in interfirm networks: the paradox of embeddedness. Administrative Science Quarterly, 42(1), 35-67.

Uzzi, G. (1996). The sources and consequences of embeddedness for the economic performance of organizations: The network effect. American Sociological Review, 61(4), 674-698.

Vanhamme, J., Lindgreen, A., \& Reast, J. (2012). To Do Well by Doing Good: Improving Corporate Image Through Cause-Related Marketing. Journal of Business Ethics, 109, 259-274. 
Weerawardena, J. \& Mort, G. S. (2006). Investigating social entrepreneurship: A multidimensional model. Journal of World Business, 41(1), 21-35.

Williams, A.P., \& Taylor, J.A. (2013). Resolving Accountability Ambiguity in Nonprofit Organizations. Voluntas, 24, 559-580.

Williamson, O.E. (1979). The governance of contractual relations. Journal of Law \& Economics, 22(2)' 233-261.

Yin, R. K. (1994). Case study research: Design and methods. Newbury Park, CA: Sage.

Yin, R. K. (2003). Case study research: design and methods. Newbury Park, CA: Sage.

Yin, R. K. (2009) Case Study Research: Design and Methods. $4^{\text {th }}$ Ed., Sage Publications, Thousand Oaks CA.

Z. Wang, Z., Jean, R., \& Zhao, X. (2020). The Direct and Indirect Impact of Relational Ties on Innovation Performance: An Empirical Study in China. IEEE Transactions on Engineering Management, 67(2), 295-308.

Zafeiropoulou, F. A. \& Koufopoulos, D. N. (2013). The Influence of Relational Embeddedness on the Formation and Performance of Social Franchising. Journal of Marketing Channels, 20(1-2), 73-98.

Zahra, S. A., \& George, G. (2002). The Net-Enabled Business Innovation Cycle and the Evolution of Dynamic Capabilities. Information Systems Research, 13(2), 147150. 
Zahra, S. A., Gedajlovic, E., Neubaum, D. O., \& Shulman, J. M. (2009). A typology of social entrepreneurs: Motives, search processes and ethical challenges. Journal of Business Venturing, 24(5), 519-532.

Zhu, Y., Rooney, D., \& Phillips, N. (2016). Practice-Based Wisdom Theory for Integrating Institutional Logics: A New Model for Social Entrepreneurship Learning and Education. Academy of Management Learning \& Education, 15(3), 607-625. 
Table 1: Social impact assessment methods

\begin{tabular}{|c|c|c|c|c|}
\hline \multirow{16}{*}{$\begin{array}{l}\text { Clark, } \\
\text { Rosenzweig, } \\
\text { Long, and } \\
\text { Olsen (2003) }\end{array}$} & Function categories & Process methods & Impact methods & Monetization methods \\
\hline & \multirow[t]{9}{*}{ Definition } & Track and monitor efficiency & Tools that relate outputs and & Monetize outcomes or impact by \\
\hline & & and effectiveness of outputs, & outcomes, and attempt to prove & assigning a monetary value to them \\
\hline & & variables or indicators that & incremental outcomes relative to the & \\
\hline & & management uses to track & next best alternative & \\
\hline & & ongoing operational & & \\
\hline & & processes. Outputs can then & & \\
\hline & & be evaluated by extent of & & \\
\hline & & correlation with desired & & \\
\hline & & outcomes & & \\
\hline & \multirow[t]{5}{*}{ Examples } & Theory of change & Balanced scorecard & Social return on investment \\
\hline & & Balanced scorecard & Ongoing assessment of social & Benefit-cost-analysis \\
\hline & & \multirow{3}{*}{$\begin{array}{l}\text { Ongoing assessment of social } \\
\text { impacts }\end{array}$} & impacts & \\
\hline & & & Social return on investment & \\
\hline & & & Benefit-cost-analysis & \\
\hline & $\begin{array}{l}\text { How social value is } \\
\text { created }\end{array}$ & \multicolumn{3}{|c|}{$\begin{array}{l}\text { Inputs (what is put into the venture), activities, (venture's primary activities), outputs (results that can be } \\
\text { measured), outcomes (changes to social systems, what would have happened anyway; impact), goal } \\
\text { alignment (activity and goal adjustment) }\end{array}$} \\
\hline
\end{tabular}




\begin{tabular}{|c|c|c|c|}
\hline & Applicability to & \multicolumn{2}{|c|}{ Start up, expansion, maturity } \\
\hline & $\begin{array}{l}\text { Assessment } \\
\text { purposes/ } \\
\text { functions in } \\
\text { investment process }\end{array}$ & \multicolumn{2}{|c|}{$\begin{array}{l}\text { Diverse methods can be best suited for different purposes including: screening, partnership formation, } \\
\text { management operations, scaling, external reporting, exit and retrospective evaluation }\end{array}$} \\
\hline & Time breakdown & \multicolumn{2}{|c|}{$\begin{array}{l}\text { Estimates of time required to implement the method or system, expressed as the average number of days per } \\
\text { month for a full-time employee (FTEs) such as management, staff, consultant/third party and investor. }\end{array}$} \\
\hline Liket and & Pillars & Themes & Criteria \\
\hline \multirow[t]{2}{*}{ Maas (2015) } & Transparency & Reporting & $\begin{array}{l}\text { Availability of a strategic plan, availability of an annual report, content of } \\
\text { annual report (1. results in relation to goals; } 2 \text {. financial report; } 3 \text {. next } \\
\text { year's budget) }\end{array}$ \\
\hline & & Online publication & $\begin{array}{l}\text { Online publication of strategic plan, online publication of annual report, } \\
\text { online publication of board members' identities }\end{array}$ \\
\hline
\end{tabular}




\section{Organizational}

characteristics

Strategy

Board

Programmes

Design

Ownership

Evaluation
Detailed mission statement (1. primary target group of beneficiaries; 2 . envisioned social change; 3. Main activities), linkage/logic between mission statement and (main) activities, long term strategic plan (min. 3 years), SMART goals in strategic plan

Research/strategic consideration of context-analysis of other organizations with similar mission statement, research/strategic consideration of alternative activities to advance mission, cooperation with other organizations, research/strategic consideration of (results from) risk analysis, participative formulation of organizational strategy

- Clear separation between board and executives, independence of board Evidence-based (research/previous experience/ evaluations) design of activities, participative design of activities (design)

Participative design of activities (ownership), participative monitoring of activities

Participative evaluation of activities, evaluation including negative and positive (un)intended effects on other people and the environment 
Required group type (e.g. experts, beneficiaries) to be involved in the Design/Monitoring/Evaluation of the activities such as direct psycho-social and physical improvements, knowledge development, skill development and capacity building, awareness and behavioral changes, and policy

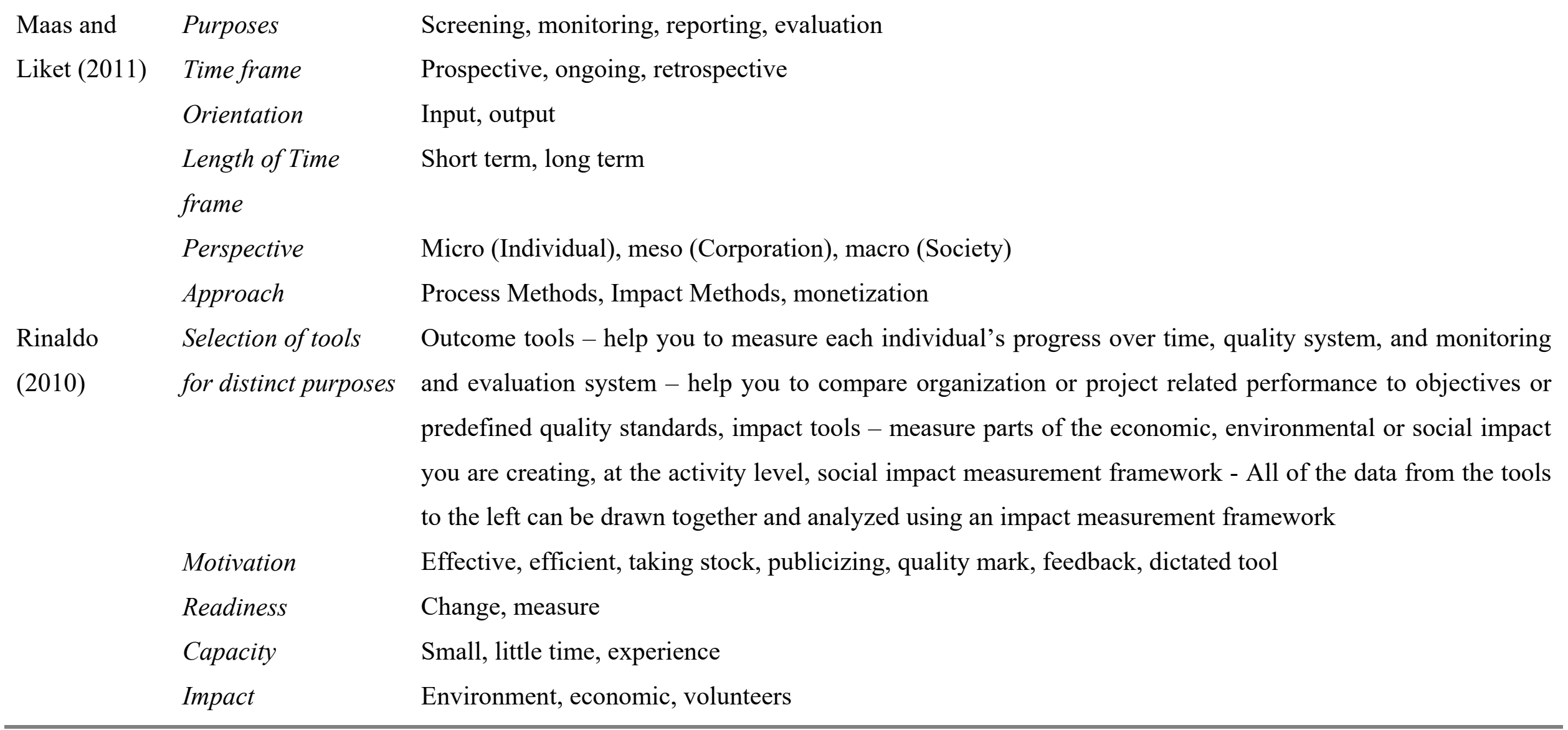




\begin{tabular}{|c|c|c|}
\hline Ridley-Duff & Qualitative methods & Social accounting and audit (SAA) \\
\hline and Bull & Quantitative & Social Return on Investment (SROI); inputs, activities, outputs, outcomes and impacts \\
\hline 2011) & methods & \\
\hline \multirow{11}{*}{$\begin{array}{l}\text { Brooks } \\
(2009)\end{array}$} & Components of & Accountability, evaluation, outcomes and impacts, effectiveness \\
\hline & measuring social & \\
\hline & value & \\
\hline & How to measure the & Developmental - outcomes attained incrementally, benchmark - comparison with a leader of some sort, \\
\hline & outcomes and & historic - some measures of success are essentially benchmarks of an organization against itself, its past \\
\hline & impacts created by & performance \\
\hline & social enterprises & \\
\hline & Methods & Social return on investment, financial vulnerability and efficiency of social enterprises (equity balance, \\
\hline & & revenue concentration, administrative costs, operation margin) \\
\hline & Effectiveness of a & Resource acquisition, efficiency, goal attainment, ability to adapt \\
\hline & social enterprise & \\
\hline
\end{tabular}




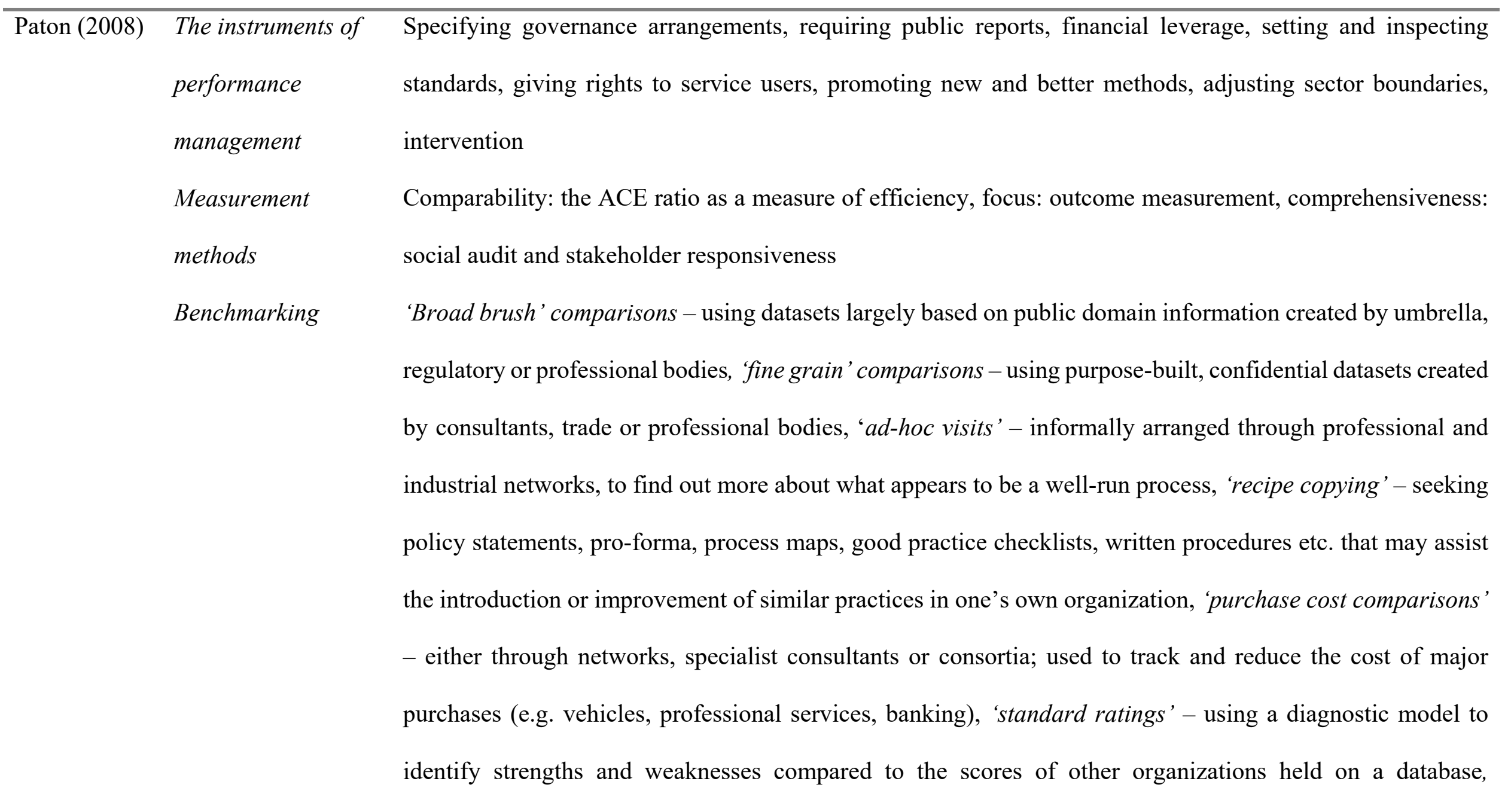


'conformity to a recognized standard' - by gaining third-party accreditation e.g. for ISO 9000 or IIP, or subscribing to a Code of Practice

Frameworks

Approaches to

methods of

performance

measurement and

improvement
The Balanced Scoreboard, dashboard for social enterprises

The committed approach, the cynical approach, the reflective approach 
Table 2: International Social Entrepreneurs, Context of Organization

$\begin{array}{llll}\text { Social Entrepreneur / Social mission } & \text { Context of social venture } & \begin{array}{l}\text { Interviewee job } \\ \text { title }\end{array} \\ \text { Interview partner } & & \end{array}$

$\begin{array}{lll}\text { Social charity } & \begin{array}{l}\text { Engage in a } \\ \text { programme of } \\ \text { practical concern } \\ \text { for the needs of } \\ \text { humanity. }\end{array} & \begin{array}{l}\text { One of the leading } \\ \text { charitable organizations in with international } \\ \text { the UK } \\ \text { offices and/or partners. } \\ \text { The area of involvement } \\ \text { includes homeless, drug } \\ \text { rehabilitation, education, } \\ \text { and employees. } \\ \text { and medical assistance. } \\ \text { The revenue that is } \\ \text { generated from } \\ \text { commercial activity } \\ \text { represents } 56.6 \% \text { of } \\ \text { overall revenue. }\end{array}\end{array}$

Control pain and A regional health service Managers,

Health charity other symptoms provider specializing in and to provide providing support to Counsellors and support to patients and their families patients patients and their according to their families individual needs in the UK with European branches. The revenue that is generated from commercial activity represents $39.2 \%$ of overall revenue

\begin{tabular}{|c|c|c|c|}
\hline Animal charity & $\begin{array}{l}\text { Relief of animal } \\
\text { suffering, care } \\
\text { and protection } \\
\text { for animals }\end{array}$ & $\begin{array}{l}\text { A very strong charity with } \\
\text { regional, national and } \\
\text { international branches } \\
\text { dedicated to providing a } \\
\text { kindness and care toward } \\
\text { the animal cause through } \\
\text { education, campaigning } \\
\text { and the application of } \\
\text { ethics, science and law. } \\
\text { The revenue that is } \\
\text { generated from } \\
\text { commercial activity } \\
\text { represents } 24 \% \text { of overall } \\
\text { revenue }\end{array}$ & $\begin{array}{l}\text { Managers, } \\
\text { Supervisors, } \\
\text { Employees }\end{array}$ \\
\hline
\end{tabular}


Table 3: Common international business elements of the case companies International element Description

Customers and stakeholders
- Domestic, regional and international focus - Support from international non-governmental organizations

- Involved in local or regional and international charities
Partners and social alliances
- Local, regional and international partners

- Social alliances through business (charity branding)

Company volunteers - International profiles

International location - UK, Europe and all continents

International products and services
- Brand and symbol for charity initiatives

- Network of social alliances

- Charity projects outside the parent company headquarters

- Donation centers and sources at different international offices 
Table 4: Common strategies of international social entrepreneurship of the case companies

\begin{tabular}{|c|c|c|}
\hline Strategies & Entrepreneurial effects & $\begin{array}{l}\text { Relational } \\
\text { Attributes (Elements) }\end{array}$ \\
\hline $\begin{array}{l}\text { Support from personal } \\
\text { ties }\end{array}$ & $\begin{array}{l}\text { Personal relationship } \\
\text { Conduits for brokerage } \\
\text { Attachment to social } \\
\text { mission }\end{array}$ & $\begin{array}{l}\text { Personal knowledge, } \\
\text { Ease, Brokering (Loyalty } \\
\text { to tie, Goal congruence, } \\
\text { Expectations), }\end{array}$ \\
\hline Access to resources & $\begin{array}{l}\text { New partners } \\
\text { Strategic alliances } \\
\text { Innovation }\end{array}$ & $\begin{array}{l}\text { Extent, Effort, Ease } \\
\text { (Interdependence, } \\
\text { Responsiveness, } \\
\text { Convenience) }\end{array}$ \\
\hline $\begin{array}{l}\text { Implement social } \\
\text { activities through ties }\end{array}$ & $\begin{array}{l}\text { Leverage relationships } \\
\text { Combining partners' } \\
\text { resources } \\
\text { Accountability }\end{array}$ & $\begin{array}{l}\text { Affect, Sociality, Ease } \\
\text { (Loyalty to tie, Goal } \\
\text { congruence, Introductions } \\
\text { to Third party) }\end{array}$ \\
\hline Share resources & $\begin{array}{l}\text { Knowledge sharing } \\
\text { Capitalize on under- } \\
\text { utilized assets } \\
\text { Expand to new markets }\end{array}$ & $\begin{array}{l}\text { Personal knowledge, } \\
\text { Extent, Ease (Identifies } \\
\text { with, Reciprocal, Goal } \\
\text { congruence) }\end{array}$ \\
\hline $\begin{array}{l}\text { Enhance trust } \\
\text { development }\end{array}$ & $\begin{array}{l}\text { Personal trust } \\
\text { Trust competence } \\
\text { Co-evolution }\end{array}$ & $\begin{array}{l}\text { Sociality, Extent } \\
\text { Obligations (Social } \\
\text { activities, Frequency, } \\
\text { Norms) }\end{array}$ \\
\hline
\end{tabular}


Table 5: Social alliances and international synergy

$\begin{array}{lll}\text { Case companies } & \text { Synergetic partner } & \begin{array}{l}\text { Enhancement from } \\ \text { synergetic co-action }\end{array}\end{array}$

Social charity

Food banks, Retailers,

Alliances to fulfil social

Religious centers

mission while generating

publicity through

corporate social

responsibility in

partnership with both not-

for-profit and commercial

organizations

Positive synergy for brand reputation

Health charity

Hospitals, Care homes

Increase donations through government health providers and private hospitals in joint awareness efforts and support from patients, family and volunteers.

Brand reputation enhances credibility and fundraising

Animal charity

Volunteers, Animal food

Information and referral to manufacturers, Animal create awareness and training centers campaign for volunteers and donations. Publicity between the animal charity and commercial organizations through support to care for and protect animals.

Provide an innovative solution to share resources and gain publicity. 
Table 6: An example of the role of relationship development in synergistic social impact

\begin{tabular}{lll} 
Partners & Social charity offers & Synergistic social impacts \\
\hline \multirow{3}{*}{ Portal partners } & - Advisory tools with partner & \\
& $\begin{array}{l}\text { brand for inclusion in own } \\
\text { website; }\end{array}$ & $\begin{array}{l}\text { - Contribution to disadvantaged } \\
\text { and poor, which can be } \\
\text { quantifiable (e.g., number of }\end{array}$ \\
& - Analytics tool to check & meals served); \\
utilization; & - Shelter and housing of \\
& homeless people; \\
& - Favorable national and \\
& international image through \\
& engagement for poverty \\
& reduction.
\end{tabular}

\begin{tabular}{|c|c|c|}
\hline $\begin{array}{l}\text { Commercial } \\
\text { partners }\end{array}$ & $\begin{array}{l}\text { - Co-marketing and branding to } \\
\text { fulfil corporate social } \\
\text { responsibility; } \\
\text { - New target customers from } \\
\text { charity and volunteers; } \\
\text { - Product recognition from } \\
\text { awareness campaign via } \\
\text { labelling and online marketing. }\end{array}$ & $\begin{array}{l}\text { - Social capital from the } \\
\text { partnership; } \\
\text { - Knowledge of social mission } \\
\text { and contribution from } \\
\text { commercial partners; } \\
\text { - Business advice especially } \\
\text { marketing for the charity } \\
\text { organization. } \\
\text { - New products from co- } \\
\text { branding between charity and } \\
\text { commercial organizations. }\end{array}$ \\
\hline $\begin{array}{l}\text { Local } \\
\text { government } \\
\text { agencies and/or } \\
\text { municipalities }\end{array}$ & $\begin{array}{l}\text { - Community and social } \\
\text { objectives of local government; } \\
\text { - Access to database of people } \\
\text { in need of help; } \\
\text { - Support from the charity } \\
\text { organization, e.g., volunteers; } \\
\text { - Engagement with local } \\
\text { community through the charity. }\end{array}$ & $\begin{array}{l}\text { - Influence on policy for social } \\
\text { mission; } \\
\text { - Contribution to society } \\
\text { through local agencies; } \\
\text { - Sharing of resources } \\
\text { especially professional advice } \\
\text { and experts; } \\
\text { - Favorable branding in terms } \\
\text { of government services. }\end{array}$ \\
\hline
\end{tabular}


Table 7: Relational ties and accountability of the case companies

International partners $\quad \begin{aligned} & \text { Relational ties and } \\ & \text { mechanism used }\end{aligned}$
Regional and international - International associations, $\Rightarrow$ Worldwide objectives; partners, social, health and conferences; $\quad \Rightarrow$ Sharing of best industry animal charity organizations - Suppliers and service practice; providers (healthcare, $\quad \Rightarrow$ Subscription and welfare housing service, membership to charity animal food);
- Not-for-profit ethos or CSR objectives. organizations with similar social mission.

Professional and public partners in the field of health, clinical and care support
- Government agencies, $\quad \Rightarrow$ Collaboration with regulatory bodies;

- Professional associations; agreement of

- Private providers. responsibilities related to voluntary versus professional services.
Personal networks
- Conduit and brokerage: friends and family members;

- Trust and personal goals;

- Personal recommendation (e.g., volunteers).
$\Rightarrow$ Tangible not-for-profit initiatives, e.g., fund raising, awareness campaigns, increased volunteers' activity. 
Table 8: International social entrepreneurship and value creation

Strategic Mission Process Outcomes and Impact

\begin{tabular}{llll} 
Social Added & Engaged new & Using personal & International social \\
Value & international & networks to agree on & alliances with high \\
partners and created & access to resources & visibility. Innovative \\
awareness to their & between partners. & marketing and \\
respective social & Emphasis on social & commercialization of \\
mission. & benefits and CSR & non-profit mission \\
& goals. & with corporate social \\
& & responsibility \\
& & benefits. \\
\hline
\end{tabular}

$\begin{array}{llll}\begin{array}{l}\text { Empowerment } \\ \text { and }\end{array} & \begin{array}{l}\text { Effective use of } \\ \text { complementary }\end{array} & \begin{array}{l}\text { Contribution from } \\ \text { both parties in the }\end{array} & \begin{array}{l}\text { Increased support } \\ \text { from local and }\end{array} \\ \text { Social Change } & \begin{array}{l}\text { skills and expertise: } \\ \text { social change and }\end{array} & \begin{array}{l}\text { partnership with } \\ \text { regards to their }\end{array} & \begin{array}{l}\text { international } \\ \text { stakeholders }\end{array} \\ & \begin{array}{l}\text { marketing. Place } \\ \text { not-for-profit }\end{array} & \text { respective expertise, } & \text { including volunteers. } \\ \text { concerns (social, social ties, } & \text { community } & \text { The partners would } \\ \text { animal and health } & \text { engagement and } & \text { balance their interests } \\ \text { through CSR. }\end{array}$

public agenda.

$\begin{array}{ll}\text { Social } & \begin{array}{l}\text { Effective linkage of } \\ \text { Innovation }\end{array} \\ & \begin{array}{l}\text { marketization, and } \\ \text { social mission and } \\ \text { goals. Motivation to }\end{array} \\ & \text { improve health, } \\ & \text { support community } \\ \text { development, and } \\ \text { protect animal } \\ \text { rights. }\end{array}$

International reach
Fulfil not-for-profit Trust-based and social objectives through for-profit CSR activities. Social alliance model to make social tools available worldwide.
Increased awareness, marketing resources, marketing channels and sharing resources. new products (e.g., Pull marketing by packaging and joint educating consumers, development, CSR) disseminating and adoption of information (e.g., $\quad$ charity mascot. campaigns) and Benefit from gaining support from volunteerism and government. professionalism in the alliance.

New charitable business model generates revenues, alignment of social mission with CSR and improve social developing new mission, increase marketing channels. employment and volunteers. 
Table 9: Evidence of Social Actions and Accountability in Social Entrepreneurship

Social actions Social charity Health charity Animal charity

\begin{tabular}{|c|c|c|c|}
\hline $\begin{array}{l}\text { Beneficiary } \\
\text { needs } \\
\text { assessment }\end{array}$ & $\begin{array}{l}\text { - Self-help project; } \\
\text { - Beneficiaries } \\
\text { included at inception; } \\
\text { - Localized rule of } \\
\text { priority; } \\
\text { - Continuous needs' } \\
\text { assessment and } \\
\text { enhancement of } \\
\text { rehabilitation and } \\
\text { education centers. }\end{array}$ & $\begin{array}{l}\text { - Education project; } \\
\text { - Development of } \\
\text { online tools; } \\
\text { - Healthcare research; } \\
\text { - Enlargement of } \\
\text { network partners to } \\
\text { increase value creation; } \\
\text { - Development of } \\
\text { bottom-up demand }\end{array}$ & $\begin{array}{l}\text { - Semi-annual survey } \\
\text { of animal welfare; } \\
\text { - Professional and } \\
\text { sponsor types of } \\
\text { campaign; } \\
\text { - Application of } \\
\text { science and law to care } \\
\text { for and protect } \\
\text { animals. }\end{array}$ \\
\hline Social alliances & $\begin{array}{l}\text { - Public social } \\
\text { service } \\
\text { organizations; } \\
\text { - Tenants' } \\
\text { associations; } \\
\text { - International and } \\
\text { domestic cultural } \\
\text { events. }\end{array}$ & $\begin{array}{l}\text { - Health centers; } \\
\text { - Municipalities; } \\
\text { - Public relations } \\
\text { partners; } \\
\text { - Network of private } \\
\text { partners (private } \\
\text { hospitals, clinics) }\end{array}$ & $\begin{array}{l}\text { - Welfare officers; } \\
\text { - Professional services; } \\
\text { - Animal rights groups. }\end{array}$ \\
\hline
\end{tabular}

\begin{tabular}{llll} 
Accountable & - Quality control and & - Independent from & - Practical knowledge \\
attributes & management; & private and government & and application; \\
& - Standard operating & hospitals; & - Audit of awareness of \\
& procedures; & - Subscribe to latest & animal care; \\
& - Annual audit of & medical research and & - Animal relief centers; \\
& social activities. & findings; \\
& & - Scientific approach to \\
& impact & \\
\hline
\end{tabular}

